and 1879 he was making known not only the Uintatheres (his so-called Dinocerata) of the Eocene of the Western States, but likewise the huge Jurassic Dinosaurs like Brontosaurus and Atlantosaurus, as well as the Toothed Cretaceous birds of Kansas. It was during this period, too, that the world was excited by his discovery of the pedigree of the horse, which fortunately came just when an actual example was urgently needed to solidify the foundations of the evolutionary hypothesis.

On this side of the Atlantic we are, perhaps, too apt to regard Marsh in the light of what used to be called a closet naturalist. But he was in reality a courageous and intrepid explorer, who between the years 1869 and 1888 is stated to have crossed the Rocky Mountains no less than twenty-one times. And in the early days of his explorations, before the opening-up of the country by railways, such expeditions contained no slight elements of danger. Not only were there difficulties of the road and inclemencies of climate with which to contend, but hostile Indians were often on his track; and we have heard from the explorer's own lips accounts of some of the perils to which he has been exposed on trips of this description.

We have said that it was between 1869 and 1879 that the great bulk of the early descriptive palæontological work of Marsh took place ; and by the latter date he had leisure to undertake more elaborate and detailed memoirs. Accordingly, we find the quarto monograph on "Odontornithes" making its appearance in I880, and that on "Dinocerata" four years later. We believe that similar monographs on the Titanotheres and Dinosaurs were in contemplation, and the plates for them prepared ; but for some reason, into which we need not inquire, these were never issued. A smaller memoir on the lastnamed group was, however, published in 1896 . Whatever may be the final judgment as to the value of the literary matter in the two quarto memoirs, the beauty and exactness of their exquisite illustrations will render them of permanent value.

Twenty years after the discovery of the Bridger and Uinta beds-that is to say, in I889-Marsh was able to announce the discovery of numerous remains of Cretaceous Mammals in the Laramie formation of Dakota and Montana. And although he was not absolutely the first to make the discovery, the number of specimens he obtained first put the occurrence of mammals in these beds on a firm footing. About this time he was also engaged in making known the gigantic Horned Dinosaurs of the Laramie, whose huge bulk and uncouth forms made them even more marvellous than their predecessors of the Jurassic.

And here it may be mentioned that Marsh by no means confined his investigations to palæontology, frequently entering upon questions of the age of strata. A remarkable instance of this is a paper urging that the British Wealden strata should be regarded as of Upper Jurassic rather than of Lower Cretaceous age ; a communication which, we think, has scarcely received all the attention that it deserves at the hands of European workers.

What will be the final verdict in regard to Marsh's life-work, it is too early to attempt to forecast. As a collector and explorer he had great and unrivalled opportunities; and in this part of his task, at least, he rose fully to the occasion. He saw his opportunity of making a great name, and he took it. And yet, perhaps, this is scarcely a fair way of putting it, for there is little doubt that Marsh had a strong and innate love for his work, which would have led him to be a palæontologist under any circumstances.

Being a man of great determination and strength of will, he, like many others of the same turn of mind, could ill brook contradiction; and he was accordingly somewhat too apt to insist on his own views and hypotheses long after they had been proved incorrect or untenable. And it was probably this impatience of contradiction and correction that at times led him to mistake reiterated and dogmatic assertion of refuted statements for logical argument. That Marsh is entitled to claim a place in the very front rank of scientific workers is not likely to be urged; and there are, in truth, no grand and enduring generalisations associated with his name. At the same time, to paraphrase the words of the donors of the Bigsby and Lyell medals, he is undoubtedly one who has been of the most eminent service to palæontology, and has, therefore, deserved well of the science.

Allusion has already been made incidentally to certain acrimonious feelings connected with his work on the other side of the Atlantic. May we venture to hope that in the future his co-labourers and successors in America will endeavour to dwell on his merits rather than on his failings, and to remember that the time-honoured motto, "De mortuis nil nisi bonum," has not yet been superseded.

R. L.

\section{WIRELESS TELEGRAPHY BETWEEN FRANCE AND ENGLAND.}

M R. MARCONI is to be cordially congratulated upon the success which has attended his latest experiments in telegraphy without intervening wires. For several months he has been actively engaged in establishing communication by means of his apparatus between stations several miles apart. He has gradually increased the distance between the stations, and has now succeeded in exchanging messages across the Channel. The Times of yesterday prints the following message transmitted by wireless telegraphy from France, and the communication possesses particular interest on account of the fact that it is the first press message sent across the Channel by the wireless telegraph system.

\section{"Wimreux, March 28.}

"Communication between England and the Continent was set up yesterday morning by the Marconi system of wireless telegraphy. The points between which the experiments are being conducted are South Foreland and Wimreux, a village on the French coast, two miles north of Boulogne, where a vertical standard wire, 150 feet high, has been set up. The distance is thirty-two miles. The experiments are being carried on in the Morse code. Signor Marconi is here conducting the trials, and is very well satisfied with the results obtained.

"This message has been transmitted by the Marconi system from Wimreux to the Foreland."

The Dover correspondent of the Times states that this and other messages were received and read at the South Foreland station with as much distinctness as though the termini had been connected with wires. This is a very remarkable achievement, and one that will to some extent compensate Mr. Marconi for the trouble he has taken to bring his apparatus to that state of perfection which has led to such gratifying success. The practical value of a system of telegraphy which enables messages to be exchanged across the Channel without the use of connecting wires cannot be overestimated.

The experiments were conducted by Mr. Marconi in the presence of Colonel du Pontavice, French military attaché, and Commandant Fiéron, naval attaché in London; Captain Ferrier, representing the French Government, and M. Voisenat, of the French telegraph service. The results obtained have placed the efficiency of Mr. Marconi's instruments beyond doubt, and we may hope soon to see the establishment of a regular system of communication with the continent by means of telegraphy without connecting wires.

NO. I 535, VOL. 59] 